\title{
Constructing Value Co-Creation Behavior on Loyalty to Community of Organic Food Products in Indonesia
}

\author{
Maria, Maya ${ }^{1^{*}} \quad$ Ujang Sumarwan $^{2^{*}} \quad$ Ahmad Sulaeman, Agus W. Soehadi ${ }^{3^{*}}$ \\ 1.School of Business IPB University, Jl. Raya Pajajaran, Babakan, Kecamatan Bogor Tengah, Kota Bogor, Jawa \\ Barat, Indonesia \\ 2.Faculty of Human Ecology, J1. Kamper Kampus IPB Dramaga, Bogor, Indonesia \\ 3.School of Business and Economics, Universitas Prasetiya Mulya, Jalan H.R. Rasuna Said Kav. C5 \\ Setiabudi, Jakarta, Indonesia
}

\begin{abstract}
The awareness of consuming healthy food has been increased. It leads to the increasing demand for organic food products. On the other side, there are obstacles to developing the organic product business due to the low level of objective knowledge of the Indonesian people towards organic products, as well as doubts over the authenticity of organic products on the market. This study aims to develop the value co-creation behaviors and perceived values of a growing community to share knowledge of organic food products with the public. Participation and interaction among the community have been enriched the method of research using simple random sampling that involved 385 respondents in 4 organic product communities. The results showed that the main behaviors that must be overcome to improve the loyalty of organic-food-products community members are participation and citizenship behavior. Having these results, the recommended policy direction is to increase the perceived benefits of community participation. Further studies are needed to refine and build more comprehensive models that integrate theoretical constructs related to other perspectives and contexts.
\end{abstract}

Keywords: loyalty to community, organic-food-products, perceived values, value co-creation behavior

DOI: $10.7176 / \mathrm{EJBM} / 13-16-07$

Publication date:August $31^{\text {st }} 2021$

\section{Introduction}

The trend of people's lifestyles to consume foods that are safe for health and environmentally friendly, has an impact on the growth in world demand for organic products which continues to increase from year to year, including in Indonesia (Nurhidayati et al. 2008, Mayrowani 2012, Sumarwan et al. 2013, Sulaeman 2016 in Astuti et al. 2016, Hubeis et al. 2013). Organic products that are free from synthetic chemicals or do not harm the health of the human body and the environment also attract attention both at the producer and consumer levels (Mayrowani 2012, Nurhidayati et al. 2008). However, Indonesia's organic market is still experiencing obstacles, including being limited to the upper middle-class economy in urban areas (Nurhidayati et al. 2008), limited to age, education level, and certain income (Slamet et al 2016), lack of promotional activities and increased promotion and low level of knowledge of human resources (Hubeis et.al 2013).

Another important thing that organic product business players need to pay close attention to is the level of consumer confidence in organic products related to guarantees. The Ministry of Agriculture has developed organic regulations, including SNI 6729-2016 concerning organic farming systems, Minister of Agriculture Regulation No. 64 of 2013 concerning organic farming systems and Head of BPOM Regulation No. 1 of 2017 concerning supervision of organic processed food. Many obstacles are experienced by organic farmers and small producers to obtain organic certification, especially regarding the cost of certification which is still burdensome (Hubeis et al. 2013), as well as consumers who have to be charged high fees to cover the cost of certification if they buy certified organic products (SPOI 2017). One of the guarantee solutions is through the community, as has been done by the participatory guarantee system in organic agriculture (PAMOR) which involves producers themselves and other parties (traders, consumers, NGOs, the government) in the assessment and recognition of compliance with organic standards initiated by the Indonesian Organic Alliance. (AOI). Another example is the guarantee in the community carried out by the Indonesian Organic Community (KOI) in collaboration with the White Flower Community.

Previous research on knowledge sharing through communities has not been conclusive. The limitation of research on the effect of social capital on value co-creation (VCC) on knowledge sharing is the absence of perceived value variables (Hung et al. 2013). For this reason, this study combines the research of Hung et al. (2013) with research by Gummerus et al. (2017) who investigated the effect of community members' perceived benefits on loyalty to community. This research is also based on Laud and Karpen (2017) which investigates the antecedent and consequence factors of value co-creation behavior (VCB) in a service system (a service system). Variables that represent value co-creation activities behavior are based on the study of Yi and Gong (2013), namely consumer participation behavior (CPB) and consumer citizenship behavior (CCB) variables.

This study examines the process of value co-creation in behavior among community members with a 
service dominant logic (SDL) approach, by looking at the influence of relational capital antecedent variables (trust, commitment, reciprocity) and cognitive capital (shared language, shared values, social support) on value co-creation in behavior (customer participation and customer citizenship behavior) and its effect on loyalty is mediated by the perceived benefits of community members. The objective of this research is to analyse the effect of value co-creation values on organic food-products.

\section{Literature Review and Testable Hypothesis}

\subsection{Relational capital}

Understanding social relationships begins with the motivation for the participants to join a group or network that expands their self-understanding of certain beliefs or values. In this case, the concept of social capital is used as part of this research study to understand how a relationship occurs in a community as stated by Nahapiet and Ghoshal (1998) and Harpham (2002). Relational capital is one of the variables that explain social capital, which relational capital includes trust, commitment, reciprocity, and identification of self-worth with the group (Nahapiet \& Ghoshal 1998). Hung et al (2013) explain relational capital as personal relationships so that a person develops himself with others by doing social interactions. The higher the quality of relational capital, the stronger the atmosphere of trust, helping, and the quality of relationships in a community (Hung et al. 2013).

\subsection{Cognitive capital}

Cognitive capital represents resources that indicate shared values and social support (Nahapiet and Ghoshal 1998, Harpham 2002). Nahapiet and Ghoshal (1998) explain that the cognitive dimension of social capital is formed from attributes such as a shared code or a shared paradigm that facilitates a common understanding of collective goals and is evidence of activity in a social system. This form of social capital provides a cohesive atmosphere for health awareness and provides space for social support for individuals who are members of the social community.

\subsection{Customer Participation Behavior}

Customer participation behavior and customer citizenship behavior as the application of the concept of value cocreation to understand interactions in the community as part of the resources integration through activities of delivering and receiving information, knowledge and experience (Vargo \& Lusch 2016, Yi and Gong 2013, Laud and Karpen 2017, Yi et al. 2011). Overall, customer participation has an impact on the form of offers that are closer to the scope of customers' value creation and ultimately help sellers in creating superior value. This study explores the value co-creation behavior activity which is represented by the variables of customer participation behavior and customer citizenship behavior as stated by Yi et al. (2011). The customer participation behavior instrument in this instrument refers to what was conveyed by Yi and Gong (2013) where participation behavior can be measured by indicators of information seeking (looking for information on how to perform tasks), information sharing (providing essential information to enable the correct rendering of the service), responsible behavior (such as being cooperative and observing rules and policies) and personal interaction (courtesy, friendliness and respect).

\subsection{Customer Citizenship Behavior}

In addition to the customer participation behavior variable, the researcher also uses the customer citizenship behavior variable to see the value co-creation behavior activity in the community. Yi and Gong (2013) explained that customer citizenship behavior can be measured by indicators of feedback (giving suggestions on how to improve the service), advocacy (recommending the business to others), helping (assisting other consumers), and tolerance (willingness to tolerate). Zhang and Chen (2017) state that customer citizenship behavior can be useful for solving several problems in organizations, including being a means of delivering innovative ideas and constructive suggestions, a means of recommendation and helping fellow members or other customers as an important step for community development and management.

\subsection{Perceived Benefit Value}

Customer perceived benefit is the benefit felt by consumers as an incentive to participate in the community (Gummerus et al., 2012, Gummerus et al. 2017). Customer perceived benefit is the perception of the benefits that consumers will receive if they are involved in the value co-creation process (Saarijarvi 201, Dong et al. 2014, Alves et al 2016). Perceived benefits are described as being able to influence members' commitment to the community (Kuo and Feng 2013) and perceived benefits are also indicated to have an effect on loyalty to the community (Gummerus et al 2012). Akman (2016) showed that the outcomes of value co-creation activities are in the form of values: social, emotional, utilitarian, and value for effort. Perceived benefit values are the outcome of customer participation in value co-creation activities in the community in accommodating a service offered. Nambisan and Baron 2009, Kuo and Feng 2013, Brodie et al 2013, Dholakia 2014, Gummerus et al 2017 , 
Sihlman 2012, and Alves 2016). In identifying the perceived benefits of consumers in the community, Gummerus et al. (2017) used informational benefit, social benefit, and hedonic benefit variables to see their effect on loyalty to community. The perceived benefit variable as an outcome of value co-creation activities can influence future participation behavior (Nambisan and Baron 2009). This research used indicators of informational benefit, emotional benefit, and social benefit to measure the perceived benefit variable according to the results of the study by Sheth et al. (1991).

\subsection{Loyalty to the Community}

Studies used loyalty to community as a dependent variable have found that benefits from community participation have a positive effect on loyalty to community (Gummerus et al. 2017, Gummerus et al. 2012, Kim et al. 2004, Shang at al. 2006). The application of the concept of loyalty to community in this research adapted from studies on loyalty to community to assess the performance of a community (Koh and Kim 2004). The measurement instrument of this research was based on the results of the study of Dick \& Basu (1994) and Lin (2010) measures community loyalty behavior with an instrument that emphasizes the intention of community members to remain loyal or have commitment is more on the behavioral aspect of loyalty. Lin (2010), among others, in the form of self-strengthening aspects to continue participating in community activities, suggesting/recommending friends and relatives to join the community, and expressing positive values about the community to others.

\section{The Effects of Cognitive Capital on Customer Participation Behavior and Customer Citizenship Behavior}

Cognitive capital as part of social capital is one of the antecedent variables that motivates participants to join the community to carry out value co creation activities (Alves et al. 2016). The formulation of the hypothesis on how the influence of cognitive capital on value co creation activities in this research is based on the study of Hung et al. 2013, Chang and Chuang 2011, and Bolino et al. 2009. It is explained that social capital has an influence on the knowledge sharing intention of members in participating and becoming community members, for that the determination of the hypothesis in this research is:

H1: Cognitive Capital has a positive influence on Customer Participation Behavior

H3: Cognitive Capital has a positive influence on Customer Citizenship Behavior

\section{The Effects of Relational Capital on Customer Participation Behavior and Customer Citizenship Behavior}

This study uses relational capital as an antecedent variable that motivates participants to join the community to carry out value co creation activities to obtain perceived benefits (Alves et al. 2016, Hung et al. 2013). Studies show that relational capital/embeddedness and cultural embeddedness have a significant effect on value cocreation behavior (Laud and Karpen 2017, Akman 2016). Relational capital has a positive impact on knowledge sharing in the community (Hung et al. 2013, Chang and Chuang (2011). This factor also affects citizenship behavior (loyalty, obedience, functional participation, social participation, and advocacy participation) (Bolino et al. 2009) In the context of organic communities, the relational capital variable is needed to accommodate the aspects of trust, commitment, and reciprocity which are thought to be factors that encourage participants to be interested in participating and becoming citizens of the consumer community. Community members are thought to tend to have a high level of trust in the authenticity of organic products that are socialized by the community. Thus, the proposed hypothesis is:

H2: Relational Capital has a positive influence on Customer Participation Behavior

H4: Relational Capital has a positive influence on Customer Citizenship Behavior

\section{The Effects of Customer Participation Behavior and Customer Citizenship Behavior on Perceived Benefit} Customer participation behavior and customer citizenship behavior as the application of the concept of value co creation which is based on the service dominant logic (SDL) approach to understand consumer relationships in the community (Yi and Gong 2013, Laud and Karpen 2017). Kuo and Feng (2013) confirmed the nature of research on the community, namely the existence of customer participation from value co-creation activities in the community that result in perceived benefits. Sihlman (2012) states that participation in the community affects the perceived benefits obtained from various activities participating in and connecting with the community in sharing values. In the context of organic communities, the variables of participation behavior and citizenship behavior are important variables that represent co-creation activities from the exchange of knowledge resources, skills, and experiences about organic products. In addition, community members are suspected of having perceived benefits in the form of social benefits, benefits of support/supporting, and emotional benefits on an ongoing basis over time by continuing to join the community. Thus, the proposed hypothesis is:

H5: Customer Participation Behavior has a positive influence Perceived Benefit

H6: Customer Citizenship Behavior has a positive influence on Perceived Benefit 
The Effects of Perceived Benefit on Loyalty to Community

The results of previous research stated that there was a positive influence between perceived benefits and consumer loyalty to the community (Gummerus et al. 2017, Gummerus et al. 2012, Kim et al. 2004, Shang at al. 2006, Kang and Shin (2016)). This is reinforced by the findings of Kuo and Feng (2013), namely the influence between benefits gained and community commitment. In the context of organic communities, community members who have a positive perception of benefits for organic communities are expected to continue to be loyal and continue to join and bond with the community. Loyal community members are expected to support the formation of a strong community in terms of campaigns and education on the benefits of organic products in the community. Thus, the proposed hypothesis is:

H7: Perceived Benefit has a positive influence on Loyalty to Community.

\section{Methods}

\subsection{Data Collection}

To achieve the goals of this research as well as proving the aforesaid hypotheses, we have adopted quantitative research which all the measurement items of instruments were adjusted from past literatures. This study uses primary data as a data source, in order to measure indicator variables, a Likert scale rule is used in measuring the level of agreement or disagreement of respondents with statements measuring an object. Research data collection was carried out in several communities in the areas of Jakarta, South Tangerang, and Bandung which was held in March-September 2020. Respondents were consumers of organic food products who were members of the consumer community, domiciled in Jakarta, Depok, Bogor, Tangerang, Bekasi (Jabodetabek), and Bandung. In this study, the population and samples are assumed as unknown due to unavailability of official data on the number of customer communities in these areas. The sampling method in this study is a convenience sampling approach. Sampling in this study is conducted by approaching directly members of the community to be asked to fill out a questionnaire. To test the aforesaid assumptions above, we implemented an online survey through social medias to gather data and information from the members of four organic communities (Komunitas Selaras Alam, Komunitas 1000 Kebun, Komunitas Paprika Loca, dan Komunitas Arista Montana) and we finally obtained complete samples of 385 questionnaire from customers of food organic products in order to investigate the effects of value co-creation behavior on customers' loyalty to the community.

\subsection{Data Analysis}

The construction model of this study was built based on the development of hypotheses between variables as described above. The study uses Covariance-Bases Structural Equation Model (CB-SEM) to test the theory in the modelling that the researcher developed based on the value co-creation concept approach based on ServiceDominant Logic theory. Researchers tested the causal relationship between 6 (six) latent variables, namely cognitive capital, relational capital, customer participation behavior, customer citizenship behavior, the perceived value of benefits, and loyalty to the community, as well as measuring the model and its suitability to empirical data.

\subsection{Respondents' Demography}

The results of the demographic analysis of the study showed that from 385 respondents, 43.9 percent of respondents were male and 56.1 percent of respondents were female. Respondents aged between 26-45 dominate with a percentage of 60.5 percent. The last education owned by the respondents was dominated by graduates at the undergraduate level (S1)/D4 as much as 45.2 percent. A total of 63.4 percent of respondents are married and most of the respondents have jobs as entrepreneurs/entrepreneurs ( 30.9 percent).

\section{Result and Discussion}

4.1 Measurement Model Analysis

Analysis of the measurement model is used to ensure that all indicators or observed variables meet the requirements or are valid and have good reliability. Table 1 shows the values of Average Variance Extracted (AVE), Cronbach alpha, and Composite Reliability for each construct. Based on the results shown in Table 1, it can be concluded that the validity of the convergence and internal consistency of measurements in this study is good. This is indicated by the AVE value for each construct which is above 0.5 which indicates that the convergence validity for each construct is good. Likewise, the Cronbach alpha and Composite Reliability values for each construct in this study were good. As stated by Baumgartner and Homburg (1996), that Composite Reliability is considered better in estimating the internal consistency of a construct. Based on Table 1, the Composite Reliability value for each construct in this study is above 0.6 . 
Table 1. Results of CR and AVE Research Variables

\begin{tabular}{|l|c|c|c|}
\hline \multicolumn{1}{|c|}{ Construct } & $\begin{array}{c}\text { AVE } \\
(\mathbf{V E} \geq \mathbf{0 . 5 0})\end{array}$ & Cronbach alpha & $\begin{array}{c}\text { Composite Reliability (CR } \\
\mathbf{\geq 0 . 7 0 )}\end{array}$ \\
\hline Relational Capital & 0,578 & 0,601 & 0,751 \\
\hline Cognitive Capital & 0,594 & 0,647 & 0,746 \\
\hline Customer Participation Behavior & 0,526 & 0,750 & 0,814 \\
\hline Customer Citizenship Behavior & 0,615 & 0,546 & 0,803 \\
\hline Perceived Benefit Values & 0,537 & 0,803 & 0,779 \\
\hline Loyalty to the Community & 0,527 & 0,794 & 0,816 \\
\hline
\end{tabular}

\subsection{Model Fit Test Results}

The overall fit test of the model was reviewed based on several indicators of Goodness-of-Fit, namely RMR, RMSEA, NFI, NNFI, CFI, IFI and RFI. The following is Table 2 of the results of data processing regarding the measure of Goodness-of-Fit in the research model.

Table 2. The Value of Goodness of Fit of The Main Empirical Model

\begin{tabular}{|l|l|c|c|c|}
\hline Tipe goodness of fit model & Indeks goodness of fit model & Cut-off Value & Result & Information \\
\hline \multirow{4}{*}{ Absolute fit measures } & Chi square statistic $\chi^{2}$ atau CMIN) & Small & 32,000 & Good \\
\cline { 2 - 5 } & P & $\geq 0,05$ & 0,000 & Bad \\
\cline { 2 - 5 } & GFI & $\geq 0,90$ & 0,974 & Good \\
\cline { 2 - 5 } & RMSEA & $\leq 0,08$ & 0,080 & Good \\
\cline { 2 - 5 } & Normed $\chi^{2}$ (CMIN/DF) & $\geq 0,94$ & 0,960 & Good \\
\hline Incremental fit measures & CFI & $\geq 0,90$ & 0,922 & Good \\
\hline Parsimonius fit measures & Adjusted Goodness of Fit Index AGFI & $\leq 571$ & God \\
\hline
\end{tabular}

Absolute fit measures measure the overall fit of the model (both the measurement model and the structural model together (Tabachnick and Fidell, 2001, Hair et al., 2014). The absolute fit measures value shown by CMIN, CMIN/DF, GFI, and RMSEA in this study gave varied results. The CMIN value of 32,000 is still categorized as good because the difference between the unrestricted covariance and restricted covariance matrices is not too big. A low chi square value with a significance level of less than 0.05 indicates that the actual input matrix is different from the predicted input matrix (Hair et al., 2014). In other words, the suitability of this research model with the data used is not good.

The value of CMIN/DF in this study is 4.571 which means good. The recommended CMIN/DF value is between two and five, which indicates that the model fits the data (Marsh and Hocevar, 1985). Thus, the research model is in accordance with the data used.

The GFI value in this study was 0.974 , greater than the recommended one, which was 0.9 . A high Goodness of Fit (GFI) value indicates that the model's ability to extract the empirical data variance is high (Amoli and Farhoomand, 1996). This shows that this research model is good.

The RMSEA value in the study was 0.080 . Goodness of fit that can be expected when the model is estimated in the population. The recommended RMSEA value between 0.05 to 0.08 is an index for the acceptance of the model that shows a close fit of the model based on degrees of freedom (Hair et al., 2014). Thus, the RMSEA value generated in the study can be categorized as good (Tabachnick and Fidell, 2001).

Incremental fit measures are measures to compare the proposed model with other models specified by the researcher (Tabachnick and Fidell, 2001; Hair et al., 2014). The value of incremental fit measures shown by CFI in this study is 0.960 which means good. The recommended value is CFI > 0.9 (Hooper et al. 2008). The CFI value is very good for measuring the level of acceptance of a model (Hooper et al. 2008). Thus, the research model can be well received.

The parsimonious value of fit measures shown by AGFI in this study was 0.922 . The recommended value is if AGFI has a value equal to or greater than 0.9 (Hair et al., 2014). However, in this study the AGFI value was still categorized as good (Tabachnick and Fidell, 2001).

\subsection{Results of Structural Model Fit}

Testing the structural model of this study was conducted to predict causality between latent variables to reveal the validity of the theoretical model built in this study through testing research hypotheses (Hair et al., 2010). Structural model testing is carried out by evaluating the path coefficient value and the $t$ statistic value or the Critical Ratio (CR) value for the significance test between constructs in the structural model (Anderson and Gerbing 1988; Hair et al. 2010). 
Table 3. Beta Coefficients Between Variables and t-count on The Structural Model

\begin{tabular}{|c|c|c|l|l|}
\hline Research hypothesis & $\begin{array}{c}\text { Path } \\
\text { coefficient }\end{array}$ & $\begin{array}{c}\text { Critical Ratio } \\
(\text { CR }=\mathbf{t}\end{array}$ & \multicolumn{1}{|c|}{ Direction } & \multicolumn{1}{|c|}{$\begin{array}{c}\text { Hypothesis } \\
\text { decision }\end{array}$} \\
\hline $\begin{array}{l}\text { H1: Cognitive Capital } \rightarrow \text { Customer } \\
\text { Participation Behavior }\end{array}$ & 0,233 & 1,405 & $\begin{array}{l}\text { Not } \\
\text { Significant, } \\
\text { positive }\end{array}$ & Not supported \\
\hline $\begin{array}{l}\text { H2: Relational Capital } \rightarrow \text { Customer } \\
\text { Participation Behavior }\end{array}$ & 0,359 & 2,013 & $\begin{array}{l}\text { Significant, } \\
\text { positive }\end{array}$ & Supported \\
\hline $\begin{array}{l}\text { H3: Cognitive Capital } \rightarrow \text { Customer } \\
\text { Citizenship Behavior }\end{array}$ & 0,427 & 3,460 & $\begin{array}{l}\text { Significant, } \\
\text { positive }\end{array}$ & Supported \\
\hline $\begin{array}{l}\text { H4: Relational Capital } \rightarrow \text { Customer } \\
\text { Citizenship Behavior }\end{array}$ & $-0,210$ & $-0,685$ & $\begin{array}{l}\text { Insignificant, } \\
\text { negative }\end{array}$ & Not supported \\
\hline $\begin{array}{l}\text { H5: Customer Participation Behavior } \\
\rightarrow \text { Perceived Benefit Values }\end{array}$ & 0,646 & 7,527 & $\begin{array}{l}\text { Appropriate, } \\
\text { positive }\end{array}$ & Supported \\
\hline $\begin{array}{l}\text { H6: Customer Citizenship Behavior } \\
\rightarrow \text { Perceived Benefit Values }\end{array}$ & 0,422 & 5,316 & $\begin{array}{l}\text { Appropriate, } \\
\text { positive }\end{array}$ & Supported \\
\hline $\begin{array}{l}\text { H7: Perceived Benefit Values } \rightarrow \\
\text { Loyalty to the Community }\end{array}$ & 0,901 & 12,701 & $\begin{array}{l}\text { Appropriate, } \\
\text { positive }\end{array}$ & Supported \\
\hline
\end{tabular}

Information: $(*)$ Significant at $t$-count $\geq 1.96$.

SEM analysis gives results in the form of coefficient estimates, standard errors, and t-statistical values for each coefficient. The selection of the significance level for each test parameter is based on the theoretical justification concerning the proposed relationship. The assessment of the suitability of the structural model of the SEM structural analysis is presented in Table 3 and Figure 1. Figure 1 shows the research model after the measurement model analysis which includes the validity for each research construct.

Table 3 is the result of SEM estimation and hypothesis testing, which shows that there are two hypotheses (Hypothesis 1 and Hypothesis 4), which are not supported. This is because the value of Critical Ratio (CR) or t statistics H1 and H4 is not significant, having a CR value of less than 1.96. However, H1 has a direction that is in accordance with the hypothesis, namely the positive direction. While $\mathrm{H} 4$ has a direction that is not in accordance with the hypothesis, namely the negative direction. As is known, the recommended CR value in SEM analysis to show a good level of significance is more than 1.96 (Hair et al., 2014). The summary of the results of testing the direction and significance of the relationship between the hypothesized variables is as follows.

4.3.1 The Effect of Cognitive Capital on Customer Participation Behavior (H1)

The cognitive capital variable has no significant effect on the direction of a positive relationship to customer participation behavior with a path coefficient value of 0.233 and a t-count of 1.405 . This shows that the higher the cognitive capital, the customer participation behavioir of organic community members will increase but the effect is not significant. This influence analysis is not in line with research conducted by Laud and Karpen (2017) and Yoon and Lee (2019) which states that cognitive capital has a positive effect on value co-creation behavior (participation behavior and citizenship behavior). This means that although community members have a fairly high level of similarity between their own values and goals with community values and goals, they are not an influential factor for high participation/contribution in organic communities. Factors of trust, commitment, and reciprocity in organic communities have more influence on member participation.

4.3.2 The Effect of Relational Capital on Customer Participation Behavior (H2)

The test results show that the relational capital variable has a significant positive effect on customer participation behavior with a path coefficient value of 0.359 and a t-count of 2.013 . This shows that the higher the trust, commitment, and reciprocity felt by community members, the behavior of participating in the community will increase. The results of this study are in line with the results of research by Laud and Karpen (2017) where relational capital has a significant effect on value co-creation behavior, as well as research by Akman (2016) which explains the positive influence of social factors on value co-creation activity.

4.3.3 The Effect of Cognitive Capital on Customer Citizenship Behavior (H3)

The test results show that the cognitive capital variable has a significant positive effect on customer citizenship behavior with a path coefficient value of 0.427 and a t-count of 3.460. This shows that the higher the communication/dialogue, the similarity of values and goals, as well as social support for organic information or moral support for consuming organic products for community members, the behavior of membership (citizenship behavior) will increase. This research is in line with the research of Mpinganjira (2016) which found that social support has a positive effect on the citizenship behavior of online community members, as well as Akman's research (2016) which explains the positive influence of social factors on value co-creation activity.

4.3.4 The Effect of Relational Capital on Customer Citizenship Behavior (H4)

The test results show that the relational capital variable has an insignificant and negative effect on customer citizenship behavior with a path coefficient value of -0.210 and a t-count of -0.685 . This shows that the higher 
the trust, commitment, and reciprocity of members of an organic community, the behavior of their membership will decrease and the effect will not be significant.

The results of this study are different from Mpinganjira (2016) who found that commitment affective has a positive effect on citizenship behavior of online community members, as well as Akman's research (2016) which explains the positive influence of social factors (trust, social interaction) on value co-creation activity. The contradictory results of this study are based on the fact that citizenship behavior is not formed from relational capital (trust, commitment, reciprocity). Where members of the organic community are more dominant in having the same level of values and goals with the community in consuming more organic products to have a high sense of membership in the community (citizenship behavior).

4.3.5 The Influence of Customer Participation Behavior on Perceived Benefit Values (H5)

The test results show that the variable customer participation behavior has a significant positive correlation with perceived benefit values with a path coefficient value of 0.646 and a t-count of 7.527. This shows that the higher the behavior of participating/contributing in the community, the perceived benefit values of organic community members will increase. This is in line with Kuo and Feng (2013), Sihlman (2012), Ercsey (2017), Alves (2016) who found that the customer participation relationship from the value co-creation behavior process in the community had a significant positive effect on perceived benefits/values.

\subsubsection{The Influence of Customer Citizenship Behavior on Perceived Benefit Values (H6)}

The test results show that the variable customer citizenship behavior has a significant and positive relationship to perceived benefit values with a path coefficient value of 0.646 and a t-count of 7.527. This shows that the higher the citizenship behavior, the perceived benefit from the value co-creation activities of members of the organic community.

The results of this study are in line with Ercsey's research (2017) which found that factors of customers' citizenship behavior as a manifestation of value co-creation activities have a significant effect on perceived value. This study is also in line with the findings of Laud and Karpen (2017) and Alves (2016) where value co-creation behavior (participation behavior and citizenship behavior) has a positive effect on outcome values.

4.3.7 The Influence of Perceived Benefit Values on Loyalty to the Community (H7)

The results of the influence test show that the perceived benefit values variable has a significant positive effect on loyalty to the community with a path coefficient value of 0.901 and a t-count of 12.701 . This shows that the higher the perceived benefit values obtained by organic community members, the loyalty to the community will increase.

The results of this study are similar to the results of Kang and Shin (2016) which states that there is a significant positive influence of consumers' perceived benefits (functional, experiential, and symbolic) on virtual brand community loyalty. This study is also in line with the results of Chen and $\mathrm{Hu}(2010)$ where perceived value has a strong influence on customer loyalty at coffee outlets.

\subsection{Buying Behavior and Respondents Perception of Organic Integrity}

From this study, $36.9 \%$ of respondents have expenses for purchasing organic products a month in the total price range of Rp. 200.001 .00 - Rp. 500,000.00 and the most purchases of organic products are vegetables by $37.4 \%$. The most frequently used media to interact in the community is through whatsapp by $84.7 \%, 236$ respondents know more information about organic product offerings that are consumed through whatsapp and as many as 231 respondents know through social media; expenditure in a month on food and beverages, namely with shopping transactions above Rp. 2 million as much as $37.1 \%$.

As many as $67.8 \%$ view the need for organic certificates on products purchased or obtained from the community, because respondents become more confident in their organic integrity in meeting organic SNI criteria $(56 \%)$. A total of $62.9 \%$ of respondents view that organic products circulating in the market are absolutely necessary to have organic certificates even though they make prices more expensive so that respondents see that self-claiming is not enough.

\section{Conclusion}

Based on the analysis and discussion that has been described, it can be concluded: 1) Cognitive capital has been shown to have an insignificant effect on creating customer participation behavior, but has a significant effect on customer citizenship behavior of members of the organic community in carrying out value co-creation activities; 2) Relational capital is proven to have an effect on creating customer participation behavior, but it does not have a significant effect on customer citizenship behavior of members of the organic community in carrying out value co-creation activities; 3) Customer participation behavior and customer citizenship behavior as a manifestation of value co-creation activities in the community are proven to have an effect on the perceived benefit values of organic community members; 4) Perceived benefit values have a strong effect on the loyalty of members to the organic community.

The study of value co-creation often leads to the creation of an increase in the quality of the value of the 
product or service offered. Studies in marketing studies with the value co-creation approach are mostly based on the theory of service-dominant logic which has implications for satisfaction, loyalty, and so on. This study discusses the social capital approach as an antecedent of value co-creation behavior (participation behavior and citizenship behavior) on loyalty through perceived benefits in the context of an organic consumer community. Whereas in its implementation the theory of service-dominant logic has many perspectives apart from value cocreation behavior in the context of organic communities where there are other aspects such as technology, social responsibility, and ecology.

Further studies are needed to refine and build more comprehensive models that integrate theoretical constructs related to other perspectives and contexts. The additional consequences should receive more attention, such as word of mouth, willingness to pay more, consumption level, or future participation (Srinivasan et al 2002, Lecrelercq et al 2016). Future research also can examine the role of moderators such as customer personality and relationship age. Therefore, future studies are advised to build a more comprehensive theoretical and empirical study so that it will contribute to the enrichment of value co-creation studies in the communities and other contexts.

\section{References}

Akman, H.M., (2016), "Value Co-Creation in Online Collaborative Communities: Exploring The Drivers and Outcomes of Value Co-Creation Activities from The Individual Community Member Point of View, [Dissertation], The University of Adelaide Business School.

Alves H., Ferreira, J.J. \& Fernandes, C.I., (2016), “Customer's Operant Resources Effects on Co-Creation Activities", Journal of Innovation \& Knowledge 1(2), 69-80, doi: 10.1016/j.jik.2016.03.001.

Amoli, J.E. and Farhoomand, AF. (1996), "A structural Model of End User Computing Satisfaction and User Performance". Information \& Management Research 30 (1996,) 65-73.

Anderson, J.C., \& Gerbing, D.W. (1988). "Structural equation modeling in practice: A review and recommended two-step approach", Psychological Bulletin 103(3), 411-423, doi:10.1037/0033-2909.103.3.411

Baumgartner, H., \& Homburg, C. (1996), "Applications of structural equation modeling in marketing and consumer research: A review”, International Journal of Research in Marketing 13(2), 139-161. doi:10.1016/0167-8116(95)00038-0

Bolino, M.C., Turnley, W.H., \& Bloodgood, J.M., (2009), Citizenship Behavior and Social Capital in Organizations", Academy of Management Journal 27(4), 505-522.

Hair, JF. et al. (2014), "Multivariate Data Analysis", 7th edn. Edinburgh Gate, Pearson Education Limited, doi: 10.1111/j.1467-9574. 1962.tb01184. x.

Head of BPOM, (2017), "Supervision of Organic Processed Food", Available at: https://standarpangan.pom.go.id/dokumen/peraturan/2017/PerKa_BPOM_No_1_Tahun_2017_Pengawasan Pangan_Olahan_Organik.pdf.

Chang, H.H. \& Chuang, S.S., (2011), "Social Capital and Individual Motivations on Knowledge Sharing: Participant Involvement as a Moderator", Information and Management 48(1), 9-18, doi: 10.1016/j.im.2010.11.001.

Chen, C. et al. 2017. The impacts of knowledge sharing-based valu

Chen, P.T. \& Hu, H.H., (2010), "The effect of Relational Benefits on Perceived Value in Relation to Customer Loyalty: An Empirical Study in The Australian Coffee Outlets Industry', International Journal of Hospitality Management 29(3), 405-412, doi: 10.1016/j.ijhm.2009.09.006.

Dick, A.S., \& Basu, K. (1994). “Customer Loyalty: Toward an Integrated Conceptual Framework”. Journal of the Academy of Marketing Science 22(2), 99-113.

Dong, B. et al. (2014), "Effect of Customer Participation on Service Outcomes: The Moderating Role of Participation Readiness", Journal of Service Research 18(2), 1-17. Doi, 10.1177/1094670514551727.

Ercsey, I., (2017), “The Role of Customers' Involvement in Value Co-Creation Behaviour Is Value Co-Creation the Source of Competitive Advantage?" Journal of Competitiveness 9(3), 51-66.

Gummerus, J. et al. (2012), Customer Engagement in a Facebook Brand Community", Management Research Review 35(9), 857-877, doi: 10.1108/01409171211256578.

Gummerus, J., Liljnder, V., \& Sihlman, R. (2017), "Do Ethical Social Media Communities Pay Off? An Exploratory Study Of The Ability of Facebook Ethical Communities to Strengthen Consumers' Ethical Consumption Behavior", Journal of Business Ethics, Springer Netherlands 144(3), 449-465, doi: 10.1007/s10551-015-2830-y.

Hubeis, M.; Widyastuti, H.; Wijaya, N.H., (2013), “Prospek Pangan Organik Bernilai Tambah Tinggi Berbasis Petani”, Bogor, IPB Press.

Hung, S.W., Lin, J.Z., \& Chen, P.C., (2013), "How Social Capital Influences Health Community Members' Adoption of Organic Foods," British Food Journal 115(11), 1564-1582, doi: 10.1108/BFJ-12-2011-0303.

Kang, M.A., \& Shin, D.H. (2016), “The effect of Customers' Perceived Benefits on Virtual Brand Community 
Loyalty, Online Information Review 40(3), 298-315, doi: 10.1108/OIR-09-2015-0300.

Koh, J. \& Kim, Y.G., (2004), "Knowledge Sharing in Virtual Communities: An e-Business Perspective". Expert Systems with Applications 26(2, 155-166, doi: 10.1016/S0957-4174(03)00116-7.

Kim, W.G., Lee, C., \& Hiemstra, S.J., (2004), "Effects of an Online Virtual Community on Customer Loyalty and Travel Product Purchases", Tourism Management 25(3):343-355, doi: 10.1016/S0261-5177(03)001420 .

Kuo, Y.F. \& Feng, L.H. (2013), "Relationships among Community Interaction Characteristics, Perceived Benefits, Community Commitment, and Oppositional Brand Loyalty in Online Brand Communities," International Journal of Information Management, Elsevier Ltd 33(6), 948-962, doi: 10.1016/j.ijinfomgt.2013.08.005.

Laud, G. \& Karpen, I.O. (2017), "Value Co-Creation Behaviour Role of Embeddedness And Outcome Considerations," Journal of Service Theory and Practice 27(4), 778-807, doi: 10.1108/JSTP-04-2016-0069.

Leclercq, T., Hammedi, W., Poncin, I. (2016), "Ten years of Value Cocreation: An Integrative Review", Recherche et Applications en Marketing, pp. 1-35. doi: 10.1177/2051570716650172.

Lin, C.P. (2010), "Learning Virtual Community Loyalty Behavior from a Perspective of Social Cognitive Theory", International Journal of Human-Computer Interaction 26(4), 345-360. doi: 10.1080/10447310903575481.

Mayrowani, H. (2012), "The development of Organic Agriculture in Indonesia". Forum Penelitian Agro Ekonomi 30 (2), 91-108.

Marsh, H.W. and Hocevar, D. (1985), "Application of Confirmatory Factory Analysis to the Study of Selfconcept: First- and Higher-order Factor Models and Their Invariance Across Groups", Psychological Bulletin 97(3), 562-582.

Minister of Agriculture Regulation. (2016), “Permentan Nomor 64 Tahun 2016: Organic Agriculture System', Available

at, http://perundangan.pertanian.go.id/admin/p_mentan/PERATURAN\%20MENTERI\%20PERTANIAN\%20T ENTANG\%20SISTEM\%20PERTANIAN\%20ORGANIK.pdf

Mpinganjira, M. (2016), Antecedents of Citizenship Behaviour in Online Customer Communities: An Empirical Investigation". South African Journal of Information Management 18(2), 1-9, doi: 10.4102/ sajim.v18i2.725.

Nambisan, S. \& Baron, RA. (2009), Virtual Customer Environments: Testing a Model of Voluntary Participation in Value Co-Creation Activities', Journal of Product Innovation Management 26(4), 388-406, doi: 10.1111/j.1540-5885.2009.00667.

Nurhidayati, et all. (2008), "E-Book Pertanian Organik: Suatu Kajian Sistem Pertanian Terpadu dan Berkelanjutan Integrated”, Universitas Islam Malang, Program Studi Agroteknologi Jurusan Budidaya Pertanian Fakultas Pertanian.

Saarijärvi, H. (2011), "Customer Value Co-Creation Through Reverse Use of Customer Data", [Dissertation], School of Management, University of Tampere.

Shang, R.A., Chen, Y.C., \& Liao, H.J., (2006), "The Value of Participation in Virtual Consumer Communities on Brand Loyalty". Internet Research 16(4), 398-418. Doi, 10.1108/10662240610690025.

Sheth, J.N., Newman, B.I., \& Gross, B.L., (1991), "Why We Buy What We Buy: A Theory of Consumption Values: Discovery Service for Air Force Institute of Technology." Journal of Business Research 22(2), 159-170. Available at: http://eds.b.ebscohost.com.afit.idm.oclc.org/eds/detail/detail?vid=3\&sid=c553a916c484-4f $2 \mathrm{~b}-8 \mathrm{f} 4 \mathrm{a}-$ 263242c3e223\%40sessionmgr120\&bdata=JnNpdGU9ZWRzLWxpdmU\%3D\#AN=17292155\&db=bth.

Sihlman, R. (2012), "The perceived Benefits of Online Community Participation and Their Effect on Consumer Commitment To Ethical Consumption, [Thesis], Hanken School of Economics.

Slamet, A., Nakayasu, A., \& Bai, H., (2016), "The Determinants of Organic Vegetable Purchasing in Jabodetabek Region, Indonesia', Foods 5(85), 1-18, doi: 10.3390/foods5040085.

Sulaeman, A. in Astuti et al., (2016), "Pengembangan Pertanian Organik di Indonesia”, Dewan Guru Besar IPB, Bogor, IPB Press.

SPOI, (2017), "Statistik Pertanian Organik Indonesia”, Bogor, Aliansi Organis Indonesia (AOI).

SNI, Sustainable Development Services, (2016), "Standar Nasional Indonesia untuk Sistem Pangan Organik, SNI Nomor 6729 Tahun 2016”, Available at: http://sdsindonesia.com/in/sni-6729-2016-sistem-pertanianorganik.

Srinivasan, S.S., Anderson, R., \& Ponnavolu, K. (2002), "Customer Loyalty in E-Commerce: An Exploration of Its Antecedents and Consequences”, Journal of Retailing, 78:41-50, doi: 10.1016/S0022-4359(01)00065-3.

Tabachnick, BG. and Fidell, LS. (2019), "Using Multivariate Statistics”, Boston, Pearson.

Vargo, SL. \& Lusch RF. (2016), "Institutions and Axioms: An Extension and Update of Service-Dominant Logic”, Journal of the Academy of Marketing Science 44(1), 5-23, doi: 10.1007/s11747-015-0456-3. 
Yi, Y. \& Gong T. (2013), "Customer Value Co-Creation Behavior: Scale Development and Validation”, Journal of Business Research, Elsevier Inc.,66(9), 1279-1284, doi: 10.1016/j.jbusres.2012.02.026.

Yi, Y., Nataraajan, R., \& Gong, T. (2011), "Customer Participation and Citizenship Behavioral Influences on Employee Performance, Satisfaction, Commitment, and Turnover Intention”, Journal of Business Research, Elsevier Inc 64(1), 87-95, doi: 10.1016/j.jbusres.2009.12.007.

Yoon, S. \& Lee, E.M., (2019), "Social and Psychological Determinants of Value Co-Creation Behavior for South Korean Firms: A Consumer-Centric Perspective", Asia Pacific Journal of Marketing and Logistics 31(1), 14-36.

Zhang, Y. \& Chen, L., (2017), The Impacts of Website Characteristics and Customer Participation on Citizenship Behaviors: The Mediating Role of Co-Creation Experience in Virtual Brand Communities", Advances in Applied Sociology 7,151-164.

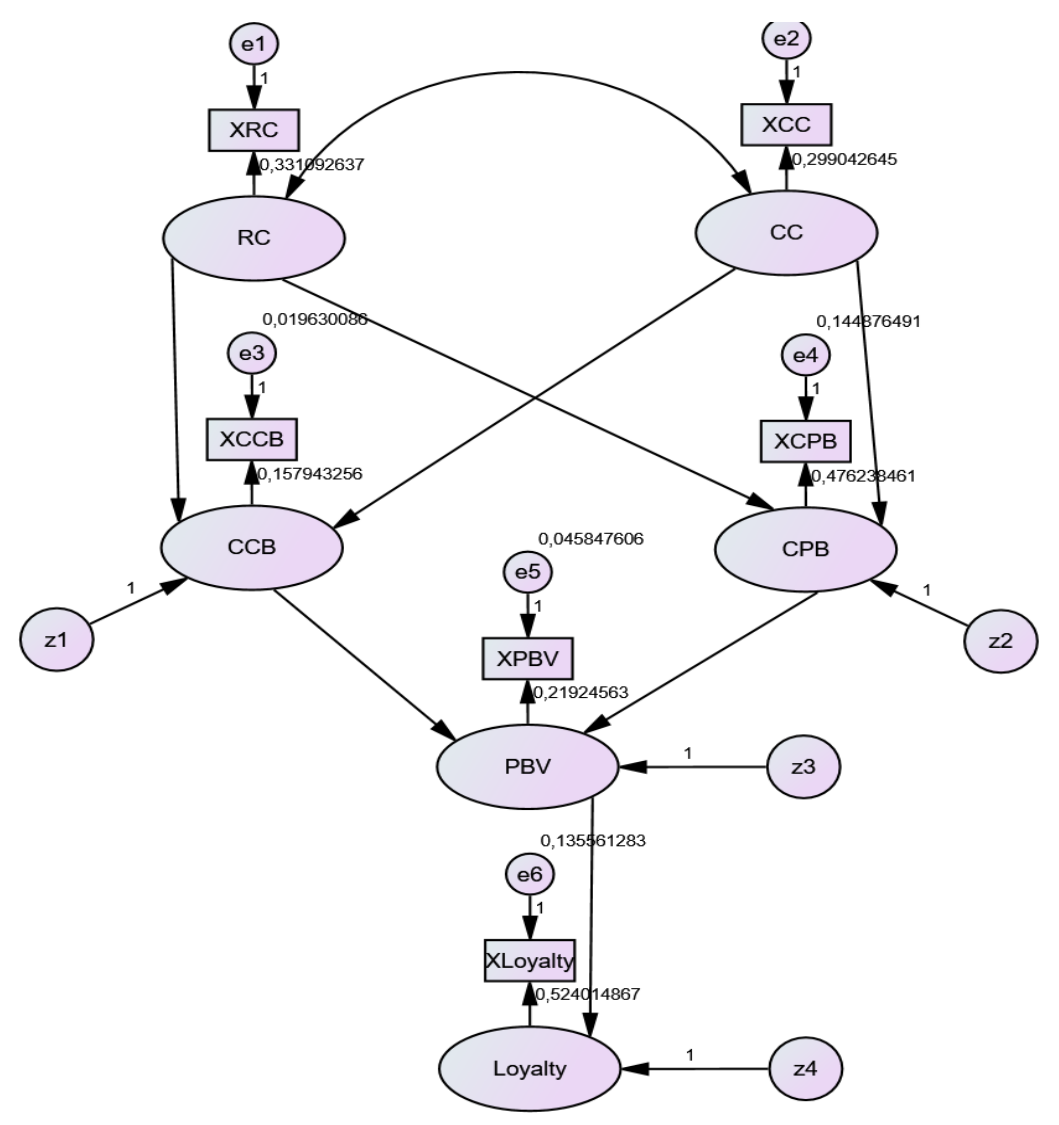

Information: $(*)$ Significant at $t$-count $\geq 1.96$.

Figure 1 Structural equation model with value $\beta$ 